Studies on the History of Society and Culture

Victoria E. Bonnell and Lynn Hunt, Editors

1. Politics, Culture, and Class in the French Revolution, by Lynn Hunt

2. The People of Paris: An Essay in Popular Culture in the Eighteenth Century, by Daniel Roche

3. Pont-St-Pierre, 1398-1789: Lordship, Community, and Capitalism in Early Modern France, by Jonathan Dewald

4. The Wedding of the Dead: Ritual, Poetics, and Popular Culture in Transylvania, by Gail Kligman

5. Students, Professors, and the State in Tsarist Russia, by Samuel

D. Kassow

6. The New Cultural History, edited by Lynn Hunt

7. Art Nouveau in Fin-de-Siècle France: Politics, Psychology, and

Style, by Debora L. Silverman

8. Histories of a Plague Year: The Social and the Imaginary in Baroque Florence, by Giulia Calvi

9. Culture of the Future: The Proletkult Movement in Revolutionary Russia, by Lynn Mally

10. Bread and Authority in Russia, 1914-1921, by Lars T. Lih

11. Territories of Grace: Cultural Change in the Seventeenth-Century Diocese of Grenoble, by Keith P. Luria

12. Publishing and Cultural Politics in Revolutionary Paris, 1789-1810, by Carla Hesse

13. Limited Livelihoods: Gender and Class in Nineteenth-Century England, by Sonya O. Rose

14. Moral Communities: The Culture of Class Relations in the Russian Printing Industry, 1867-1907, by Mark Steinberg

15. Bolshevik Festivals, 1917-1920, by James von Geldern

16. Venice's Hidden Enemies: Italian Heretics in a Renaissance City, by John Martin

17. Wondrous in His Saints: Counter-Reformation Propaganda in Bavaria, by Philip M. Soergel

18. Private Lives and Public Affairs: The Causes Célebres of Prerevolutionary France, by Sarah Maza

19. Hooliganism: Crime, Culture, and Power in St. Petersburg, 1900-1914, by Joan Neuberger 
20. Possessing Nature: Museums, Collecting, and Scientific Culture in Early Modern Italy, by Paula Findlen

21. Listening in Paris: A Cultural History, by James H. Johnson

22. The Fabrication of Labor: Germany and Britain, 1640-1914, by Richard Biernacki

23. The Struggle for the Breeches: Gender and the Making of the British Working Class, by Anna Clark

24. Taste and Power: Furnishing Modern France, by Leora Auslander

25. Cholera in Post-Revolutionary Paris: A Cultural History, by Catherine J. Kudlick 

CHOLERA IN

POST-REVOLUTIONARY PARIS 


\section{CHOLERA IN POST-REVOLUTIONARY PARIS}

A CULTURAL HISTORY

Catherine J. Kudlick 
This book is a print-on-demand volume. It is manufactured using toner in place of ink. Type and images may be less sharp than the same material seen in traditionally printed University of California Press editions.

University of California Press

Berkeley and Los Angeles, California

University of California Press, Ltd.

London, England

(C) 1996 by

Catherine J. Kudlick

\section{Library of Congress Cataloging-in-Publication Data}

Kudlick, Catherine Jean.

Cholera in post-revolutionary Paris : a cultural history

/ Catherine J. Kudlick. culture; 25 )

p. $\quad \mathrm{cm}$. - (Studies on the history of society and

Includes bibliographical references and index.

ISBN 0-520-20273-2 (alk. paper)

1. Cholera-France-Paris-History-19th

century. I. Title. II. Series.

$\mathrm{RC}_{133 .} \mathrm{F}_{9} \mathrm{P}_{334} 1996$

$614.5^{\prime} 14^{\prime} 09443609034-\mathrm{dc2} 0$

Printed in the United States of America

The paper used in this publication meets the minimum requirements of American National Standard for Information Sciences-Permanence of Paper for Printed Library Materials, ANSI Z39.48-1984.

Parts of Chapter 3 appeared in "The Culture of Statistics and the Crisis of Cholera, 1830-1850," in Re-creating Authority in Revolutionary France, ed. Bryant T. Ragan, Jr., and Elizabeth Williams (New Brunswick, N.J.: Rutgers University Press, 1992). Parts of Chapter 4 appeared in "Giving Is Deceiving: Cholera, Charity, and the Quest for Authority in 1832," French Historical Studies 18, no. 2 (fall 1993): 457-81. @ Society for French Historical Studies, 1993. 
To my parents and doctors

and in memory of Walter Bazar

for the gift of sight

and to my teachers, colleagues, students,

and friends

for their gifts of insight 
